\title{
SIFAT FISIKA MEKANIKA DAN KETAHANAN PAPAN PARTIKEL BAMBU DENGAN PEREKAT ASAM SITRAT TERHADAP SERANGAN RAYAP KAYU KERING
}

\author{
RAGIL WIDYORINI*, ARI PUSPA YUDHA, \\ GANIS LUKMANDARU, \& TIBERTIUS AGUS PRAYITNO
}

\author{
Bagian Teknologi Hasil Hutan, Fakultas Kehutanan Universitas Gadjah Mada \\ J1. Agro No. 1 Bulaksumur, Sleman 55281 \\ *Email: rwidyorini@gmail.com
}

\begin{abstract}
Research on development of citric acid as natural adhesive are still limited. Therefore this research focused on effects of citric acid content and pressing temperature on properties of particleboard made from bamboo, including its durability to the dry termite attacks. Petung bamboo particles were used as raw materials. Chemical characteristics of petung bamboo were analyzed for its extractive, lignin, holocellulose and alpha cellulose. Factors used in this research were citric acid content (0 - $40 \%)$ based on dry weight particles and pressing temperature $\left(200^{\circ} \mathrm{C}\right.$ dan $\left.220^{\circ} \mathrm{C}\right)$. Properties of the particleboard were analyzed based on Japanese Industrial Standard (JIS) A 5908 for particleboard. Fourier transform infrared spectroscopy (FTIR) analysis was used for investigating the changes of ester groups at various citric acid content and pressing temperature. The dry termite resistance was then analyzed for its weight loss and mortality after 6 weeks. The results showed that interaction between two factors affected significantly on thickness swelling, water absorption, modulus of elasticity, and modulus of rupture. Intensity of $C=O$ groups became stronger as increasing citric acid content, providing high mechanical properties and high dimensional stability. Optimum condition in this research was achieved at $20 \%$ of citric acid content and $200^{\circ} \mathrm{C}$ of pressing temperature, which the board properties met the requirement of JIS A 5908 type 8. Increasing of citric acid content would also increase the dry termite mortality. Addition of $20 \%$ citric acid at $200{ }^{\circ} \mathrm{C}$ of pressing temperature produced particleboard with the weight loss was $0.9 \%$ and $57 \%$ of the dry termite mortality.
\end{abstract}

Keywords: petung bamboo, citric acid, citric acid content, pressing temperature.

\section{INTISARI}

Penelitian mengenai penggunaan asam sitrat sebagai agen pengikat alami masih relatif sedikit. Oleh karena itu penelitian ini difokuskan pada pengaruh jumlah asam sitrat dan suhu pengempaan terhadap sifat papan partikel bambu, termasuk ketahanannya terhadap serangan rayap kayu kering. Bahan penelitian adalah partikel bambu petung. Komposisi kimia bahan baku bambu diuji untuk kadar ekstraktif, holoselulosa, lignin, dan alfa selulosa. Faktor pada penelitian ini adalah jumlah asam sitrat (0 - 40\%) berdasarkan berat kering udara partikel) dan suhu pengempaan $\left(200^{\circ} \mathrm{C}\right.$ dan $\left.220^{\circ} \mathrm{C}\right)$. Sifat fisika dan mekanika papan partikel diuji berdasarkan standar pengujian JIS A 5908. Analisis menggunakan Fourier transform infrared spectroscopy (FTIR) juga dilakukan untuk mengetahui perubahan gugus ester pada berbagai jumlah asam sitrat dan suhu pengempaan. Pengujian ketahanan terhadap serangan rayap kayu kering juga dilakukan dengan menghitung nilai pengurangan berat dan mortalitas rayap setelah 6 minggu. Hasil pengujian menunjukkan bahwa interaksi kedua faktor berpengaruh nyata terhadap nilai pengembangan tebal, penyerapan air, modulus elastisitas dan modulus patah. Intensitas gugus $C=O$ yang ditunjukkan pada puncak $1720 \mathrm{~cm}^{-1}$ semakin bertambah besar seiiring dengan semakin banyaknya jumlah asam sitrat, yang menyebabkan kekuatan perekatan dan stabilitas dimensi papan partikel menjadi semakin kuat. Kondisi 
optimum pada penelitian ini adalah papan partikel dengan penambahan jumlah asam sitrat $20 \%$ pada suhu pengempaan $200^{\circ} \mathrm{C}$ dengan kualitas yang dapat memenuhi standar JIS A 5908 tipe 8. Penambahan asam sitrat dapat meningkatkan mortalitas rayap kayu kering secara nyata. Penambahan $20 \%$ asam sitrat pada suhu pengempaan $200^{\circ} \mathrm{C}$ menghasilkan nilai pengurangan berat 0,9\% dan mortalitas rayap $57 \%$.

Kata kunci: bambu petung, asam sitrat, suhu pengempaan, jumlah asam sitrat.

\section{PENDAHULUAN}

Permasalahan emisi formaldehida yang dihasilkan oleh produk-produk komposit dengan perekat berbasis formaldehida menjadi alasan dilakukannya penelitian mengenai pembuatan atau pengembangan produk komposit berbasis perekat alam atau bahkan komposit tanpa perekat sintetis (binderless composite) (Laemsak dan Okuma, 2000; Okuda dan Sato, 2006; Widyorini et al., 2005; Widyorini et al., 2013; Xu et al., 2003). Beberapa kelemahan produk papan komposit tanpa perekat sintetis yang menjadi kendala adalah sangat tergantung pada karakteristik kimia bahan baku dan mempunyai kestabilan dimensi yang masih relatif rendah. Oleh karena itu, berbagai inovasi dilakukan seperti penambahan bahan kimia sebagai pengaktif permukaan bahan direkat diantaranya adalah asam, alkali, maupun bahan pengoksidasi seperti hidrogen peroksida. Namun demikian, penggunaan bahan-bahan tersebut mempunyai kelemahan pada masalah keamanan dan kesehatan.

Salah satu bahan pengaktif alami yang mulai dikembangkan adalah asam sitrat (2-hydroxy-1,2,3propanetricarboxylic acid) yang mengandung tiga gugus karboksil dan terbukti dapat digunakan sebagai agen pengikat pada produk moulding dari kulit dan kayu akasia (Umemura et al., 2011). Produk moulding tersebut mempunyai kekuatan yang baik, bahkan tidak terdekomposisi setelah mengalami proses pengujian perebusan secara berulang.
Ketahanan terhadap air semakin meningkat dengan meningkatnya kadar asam sitrat. Hal tersebut mengindikasikan bahwa asam sitrat dapat mengaktifkan komponen kimia di dalam kulit kayu akasia dan dapat menyempurnakan ikatan perekatan selama proses pengempaan (Umemura et al., 2012). Analisis menggunakan Fourier Transform Infrared Spectra (FTIR) memperlihatkan adanya pembentukan ikatan ester antara gugus karboksil dari asam sitrat dengan gugus hidroksil $(\mathrm{OH})$ dari kulit akasia (Umemura et al., 2011) selama proses pengempaan. Reaksi yang sama terlihat pada modifikasi selulosa dengan asam sitrat anhidrida menghasilkan ikatan ester (Thanh dan Nhung, 2009). Penelitian menggunakan asam sitrat sebagai bahan perekat atau pengikat komposit masih relatif baru dan belum banyak dilakukan, apalagi di Indonesia. Oleh karena itu, penelitian menggunakan asam sitrat sangat menarik untuk dilakukan, karena selain merupakan bahan yang ramah lingkungan, bahan ini mudah diperoleh serta harganya yang tidak mahal.

Penelitian menggunakan asam sitrat dengan komposisi 0 sampai $40 \%$ pada pembuatan produk cetakan atau moulding dari kulit dan kayu akasia memperlihatkan bahwa komposisi $20 \%$ asam sitrat atau setara dengan penambahan $25 \%$ asam sitrat berdasarkan berat kering udara partikel memberikan hasil kekuatan dan ketahanan terhadap air yang paling optimal (Umemura et al. 2011; 2012). Pada penelitian sebelumnya oleh Widyorini et al. (2013), papan partikel bambu dengan asam sitrat terbukti 
mempunyai kekuatan kualitas yang lebih tinggi dibandingkan papan partikel tanpa perekat dari bahan baku yang sama. Penambahan sampai $20 \%$ asam sitrat berdasarkan berat kering udara partikel bambu dengan suhu pengempaan 200 dan $220{ }^{\circ} \mathrm{C}$ masih memperlihatkan peningkatan kualitas secara signifikan. Untuk mengetahui kondisi yang paling optimal pada suhu pengempaan 200 dan $220{ }^{\circ} \mathrm{C}$, maka penelitian ini menggunakan konsentrasi asam sitrat $0-40 \%$. Waktu pengempaan yang digunakan 10 menit, karena hasil penelitian Widyorini et al. (2013) menunjukkan waktu pengempaan 10 menit memberikan kualitas yang lebih baik daripada waktu 15 menit. Untuk mengetahui mekanisme yang terjadi, dilakukan analisis Fourier Transform Infrared (FTIR) pada sampel bahan baku partikel dan papan partikel.

Selain sifat kekuatan papan partikel, sifat ketahanan serta keawetan juga perlu diperhatikan agar memberikan umur pakai yang lebih lama. Salah satu kendala papan partikel yang berbahan baku lignoselulosa adalah serangan serangga perusak kayu. Serangga yang dapat menyerang produkproduk papan partikel di dalam ruangan adalah rayap kayu kering. Walther et al. (2007) melakukan penelitian mengenai intensitas serangan rayap kayu kering terhadap papan serat kenaf dengan perekat fenol formaldehida dan hasilnya menunjukkan bahwa kandungan perekat juga sangat berpengaruh terhadap intensitas serangan rayap. Selama ini, belum pernah dilakukan penelitian mengenai ketahanan papan partikel dengan perekat asam sitrat terhadap serangan rayap kayu kering. Oleh karena itu, tujuan dari penelitian ini adalah untuk mengetahui pengaruh jumlah asam sitrat dan suhu pengempaan terhadap sifat fisika, mekanika, serta ketahanan papan partikel dari bambu terhadap serangan rayap kayu kering.

\section{BAHAN DAN METODE}

Partikel bambu petung merupakan limbah serutan yang diperoleh dari Bengkel Pengolahan Kayu Fakultas Kehutanan UGM, Klebengan. Untuk menyeragamkan ukuran, partikel diayak dengan menggunakan ukuran lolos $0,2 \times 0,2 \mathrm{~cm}$ atau 10 mesh, kemudian partikel dikering-udarakan. Analisis penelitian yang digunakan berupa Rancangan Acak Lengkap dengan faktor jumlah asam sitrat adalah 0 , $10,20,30$, dan $40 \%$ berdasarkan berat kering partikel, dan suhu pengempaan (200 dan $\left.220{ }^{\circ} \mathrm{C}\right)$. Masing-masing kombinasi perlakuan diulang 3 kali. Setelah dicampur dengan asam sitrat, partikel kemudian dioven pada suhu $80{ }^{\circ} \mathrm{C}$ selama kurang lebih 18 jam, kemudian dibuat mat dengan ukuran 25 x $25 \mathrm{~cm}$, kemudian dikempa selama 10 menit. Target ketebalan papan diset $0,7 \mathrm{~cm}$ dengan target kerapatan $0,9 \mathrm{~g} / \mathrm{cm}^{3}$. Setelah proses pengempaan, papan partikel dikondisikan selama kurang lebih 1 minggu sampai mencapai kondisi kering udara.

Pengujian mengacu pada prosedur pengujian Japanese Industrial Standard (JIS) A 5908 (2003) untuk papan partikel. Sifat fisika yang diuji meliputi kerapatan, pengembangan tebal dan penyerapan air setelah perendaman 24 jam pada air kondisi ruangan, sedangkan sifat mekanika meliputi kekuatan rekat internal, modulus patah, dan modulus elastisitas. Sampel sebanyak kurang lebih $50 \mathrm{mg}$ yang diperoleh dari bagian tengah contoh uji papan partikel untuk kekuatan rekat internal, kemudian dianalisis dengan menggunakan FTIR untuk mengetahui perubahan gugus-gugus kimia yang terjadi. Analisis FTIR dilakukan pada sampel yang dikempa pada suhu 200 dan $220^{\circ} \mathrm{C}$ dengan konsentrasi asam sitrat $0,10,20$, 30 , dan $40 \%$.

Analisis kimia kayu dilakukan pada beberapa parameter. Serbuk kayu setara $2 \mathrm{~g}$ berat kering tanur, diekstraksi soxhlet dengan pelarut etanol-benzena 
$(1: 2, \mathrm{v} / \mathrm{v}) \quad(\mathrm{ASTM} \mathrm{D}-1107,1984)$ serta secara terpisah dengan air panas dan air dingin (ASTM D1110 - 80, 2002). Untuk serbuk bebas ekstraktif etanol-benzena selanjutnya diukur kadar holoselulosa dan alfa-selulosa dengan metoda asam klorit (Browning 1967), serta lignin Klason (TAPPI Test Method T 222 os-74, 1992).

Pengujian terhadap serangan rayap kayu kering mengacu pada standard JIS K 1571 dengan menggunakan sampel papan partikel ukuran $5 \mathrm{~cm}$ x 5 $\mathrm{cm} \times 0,7 \mathrm{~cm}$. Selain itu, dipersiapkan satu contoh uji dengan ukuran yang sama dari papan komersil yang dijual di toko bangunan di Yogyakarta, serta satu wadah kosong tanpa pemberian contoh uji (rayap saja) sebagai kontrol. Selanjutnya, keseluruhan contoh uji dioven pada suhu $60{ }^{\circ} \mathrm{C}$ hingga diperoleh massa sebelum pengumpanan. Persiapan pengumpanan diawali dengan memasukkan 50 ekor rayap kayu kering dewasa, sehat, dan aktif ke dalam tabung gelas dan diberi penutup pada bagian atas tabung yang terbuka. Contoh uji disimpan dalam ruangan gelap dan dilakukan pengamatan mortalitas rayap setiap dua hari berturut-turut hingga enam minggu. Rayap yang sudah mati diambil dengan pinset agar tidak dimakan oleh rayap yang lain. Setelah enam minggu pengamatan, contoh uji dibersihkan dari rayap-rayap dan kemudian dikeringkan kembali dalam oven pada suhu $60{ }^{\circ} \mathrm{C}$ hingga didapat massa sesudah pengumpanan. Perhitungan mortalitas rayap dan pengurangan berat berdasarkan persentase per jumlah total rayap dan berat kering contoh uji.

\section{HASIL DAN PEMBAHASAN}

\section{Sifat Kimia Bambu Petung dan Analisis FTIR}

Komposisi kimia bambu petung yang terdiri dari holoselulosa, alfa-selulosa, lignin, ekstraktif alkohol benzena, ekstraktif air panas, dan ekstraktif air dingin, dapat dilihat pada Tabel 1. Kerapatan rata-rata papan partikel bambu petung dengan asam sitrat adalah $0,83 \mathrm{~g} / \mathrm{cm}^{3}$ dari target kerapatan 0,9 $\mathrm{g} / \mathrm{cm}^{3}$. Semua papan partikel dapat dibuat tanpa ada delaminasi. Warna papan partikel semakin gelap dengan semakin banyaknya jumlah asam sitrat (Gambar 1). Hal yang sama juga ditemukan oleh Umemura et al. (2011) yang meneliti produk cetakan kayu akasia dengan penambahan asam sitrat.

Tabel 1. Komposisi kimia bambu petung

\begin{tabular}{lc}
\hline \multicolumn{1}{c}{ Komposisi Kimia (\%) } & Penelitian ini \\
\hline Holoselulosa & $72,80^{*}$ \\
Alfa-selulosa & $48,80^{*}$ \\
Lignin & $25,72^{*}$ \\
Kelarutan dalam Alkohol-benzena & 2,16 \\
Kelarutan dalam air panas & 5,11 \\
Kelarutan dalam air dingin & 4,28 \\
\hline
\end{tabular}

*berdasarkan serbuk bebas ekstraktif (SBE)

Hasil analisis FTIR bambu dan papan partikel pada berbagai jumlah asam sitrat pada suhu pengempaan 200 dan $220^{\circ} \mathrm{C}$ ditunjukkan pada Gambar 2 dan Gambar 3. Gugus $\mathrm{C}=\mathrm{O}$ yang ditunjukkan pada puncak $1720 \mathrm{~cm}^{-1}$ terlihat pada papan partikel bambu petung dengan asam sitrat. Sebaliknya, pada bahan baku bambu petung tidak menunjukkan dengan jelas keberadaan gugus $\mathrm{C}=\mathrm{O}$. Hal ini disebabkan oleh pembentukan ikatan ester dari gugus hidroksil pada kayu dengan gugus karboksil pada asam sitrat (Umemura et al., 2011). Penggunaan asam sitrat 10, 20,30, dan $40 \%$ menunjukkan intensitas gugus yang semakin kuat. Walaupun tidak ada penambahan asam sitrat, spektrum FTIR pada papan partikel dengan asam sitrat $0 \%$ pada kedua suhu pengempaan menunjukkan puncak $1720 \mathrm{~cm}^{-1}$ yang sangat kecil. Gugus $\mathrm{C}=\mathrm{O}$ ini juga dihasilkan oleh degradasi dari hemiselulosa selama proses pengempaan panas (Widyorini et al., 2005). Perbedaan intensitas gugus $\mathrm{C}=\mathrm{O}$ pada dua suhu pengempaan pada penelitian ini tidak terlihat jelas pada spektrum FTIR. 


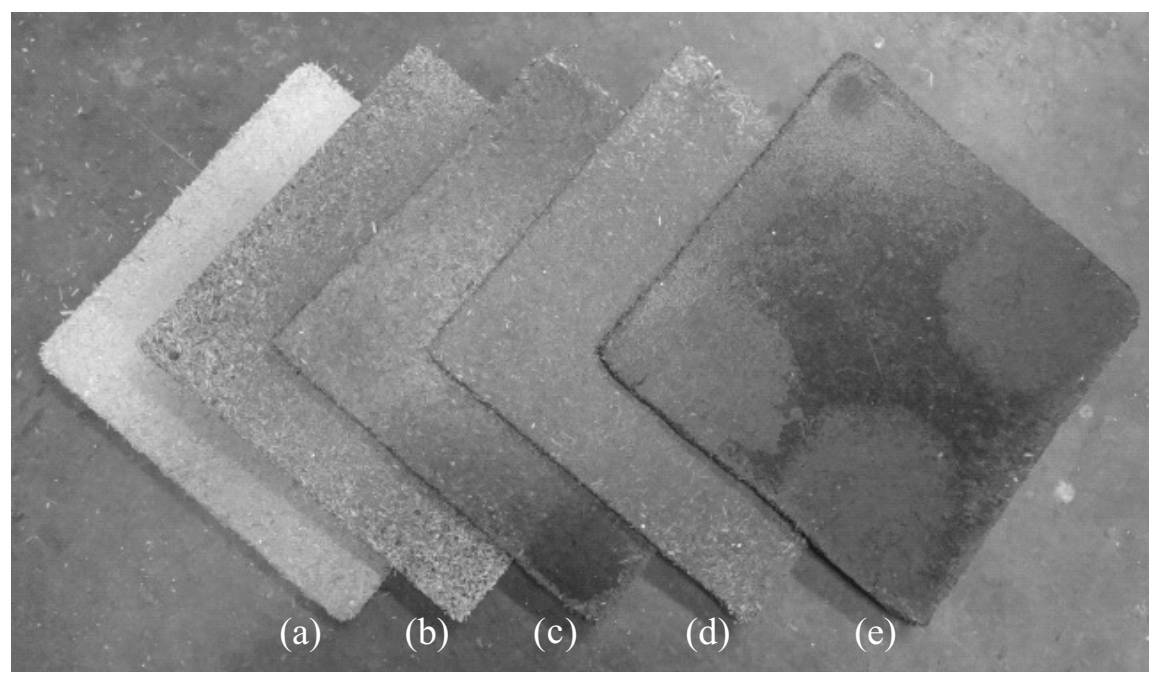

Gambar 1. Papan partikel bambu dengan berbagai variasi jumlah asam sitra1 $(0 \%=\mathrm{a}),(10 \%=\mathrm{b}),(20 \%=\mathrm{c}),(30 \%=\mathrm{d})$, dan $(40 \%=\mathrm{e})$ yang dikempa pada suhu $200^{\circ} \mathrm{C}$ selama 10 menit

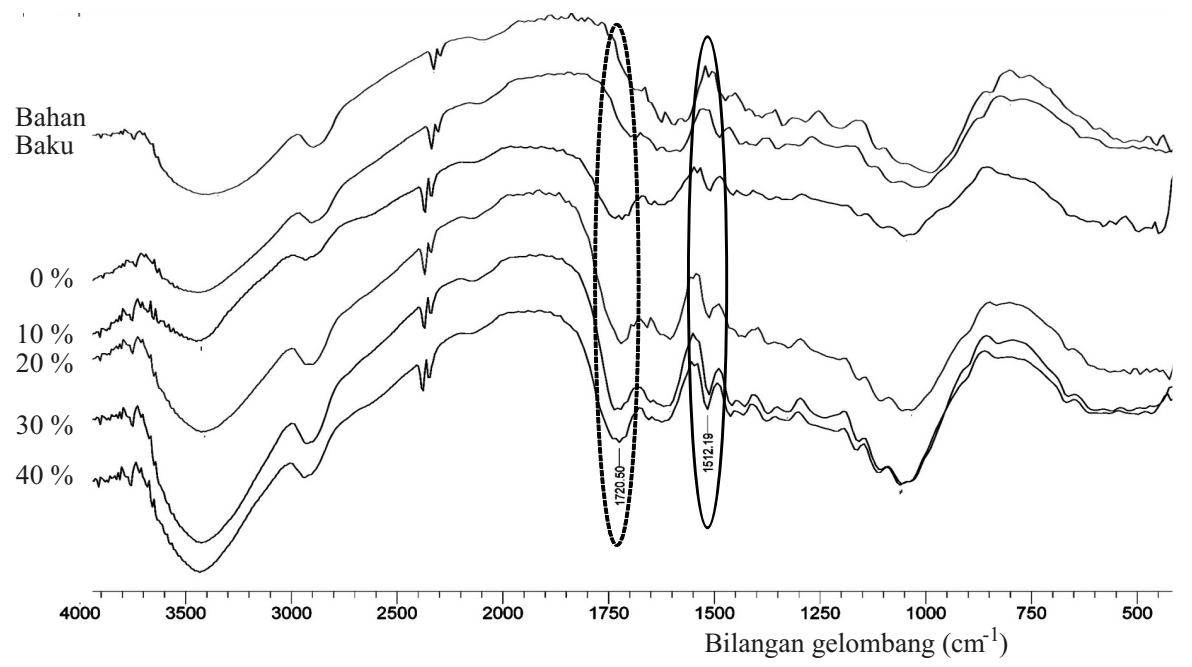

Gambar 2. Spektrum FT-IR papan partikel bambu petung (suhu kempa $200^{\circ} \mathrm{C}$ )

Keberadaan puncak $1512 \mathrm{~cm}^{-1}$ diduga berasal dari unit aromatik pada lignin. Menurut Okuda dan Sato (2006), sifat lignin ditandai dengan adanya gugus $\mathrm{C}=\mathrm{C}$ pada disekitar $1505 \mathrm{~cm}^{-1}-1510 \mathrm{~cm}^{-1}$. Walaupun perbedaan intensitas akibat suhu pengempaan yang berbeda tidak begitu nyata terlihat, tetapi penambahan asam sitrat menunjukkan intensitas yang semakin kuat. Hal tersebut mengindikasikan bahwa lignin juga berperan dalam ikatan yang terjadi. Hal yang sama juga terjadi dalam penelitian Okuda dan Sato (2006), yang menyatakan bahwa spektrum FTIR dari kenaf setelah proses pembuatan menjadi papan partikel tanpa perekat menunjukkan adanya intensitas yang sama pada puncak pita 1507 $\mathrm{cm}^{-1}$ yang merupakan turunan unit aromatik lignin.

\section{Sifat Fisika dan Mekanika}

Tabel 2 menunjukkan bahwa interaksi antar kedua faktor berpengaruh signifikan pada taraf uji 0,01 terhadap nilai pengembangan tebal, penyerapan air, dan modulus elastisitas, serta berpengaruh signifikan pada taraf uji 0,05 terhadap modulus patah. Jumlah asam sitrat berpengaruh signifikan pada taraf uji 0,01 pada semua sifat fisika maupun 


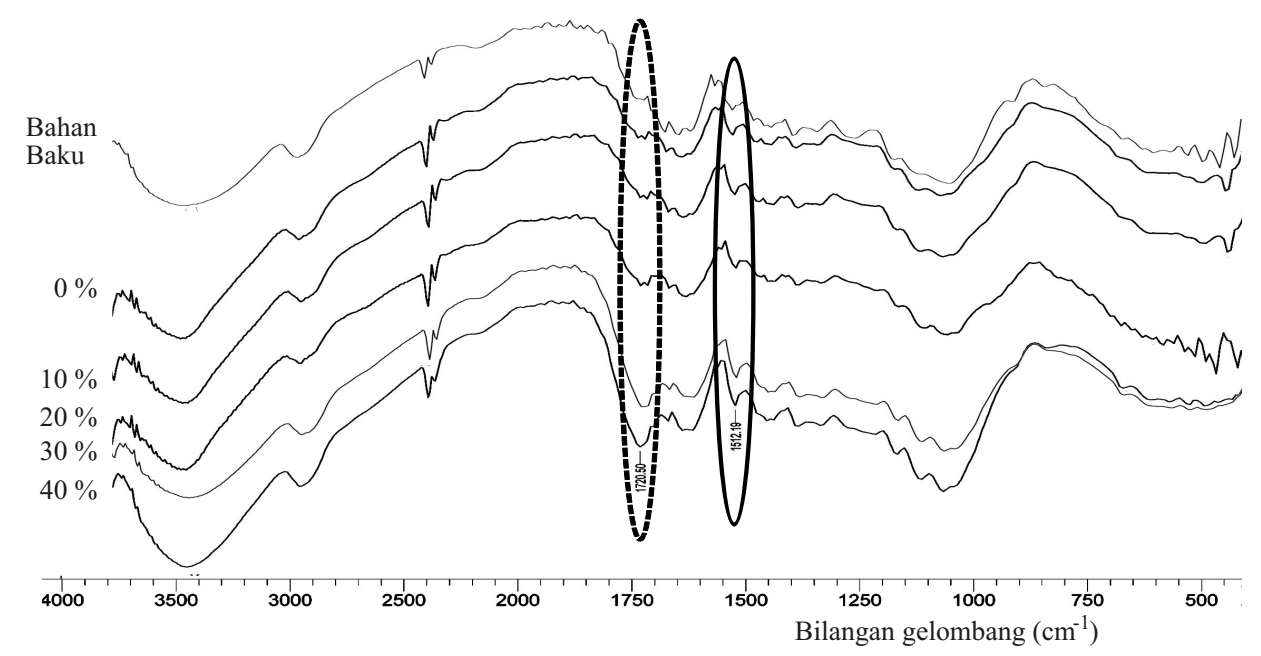

Gambar 3. Spektrum FT-IR papan partikel bambu petung (suhu kempa $220^{\circ} \mathrm{C}$ )

mekanika papan partikel. Pengaruh suhu pengempaan hanya signifikan terhadap sifat fisika papan dan kekuatan rekat internal.

Gambar 4 menunjukkan hubungan antara pengembangan tebal dan penyerapan air papan partikel bambu pada berbagai jumlah asam sitrat (0$40 \%$ ) dan suhu pengempaan 200 dan $220^{\circ} \mathrm{C}$. Nilai ini diperoleh setelah perendaman air pada suhu ruangan selama 24 jam. Semua papan partikel yang dibuat dengan penambahan asam sitrat menunjukkan kualitas yang baik dan dapat memenuhi standar JIS A 5908 (kurang dari $12 \%$ ). Semakin tinggi suhu pengempaan memperbaiki sifat fisika papan partikel, baik pengembangan tebal dan penyerapan air papan. Jumlah asam sitrat yang meningkat dari 0-40 \% menyebabkan naiknya kestabilan dimensi papan partikel. Hal ini terlihat dari nilai pengembangan tebal dan penyerapan air untuk papan partikel tanpa perekat $(0 \%)$ adalah $20 \%$ dan $69 \%$ kemudian menjadi $1 \%$ dan $10 \%$ pada penambahan asam sitrat $40 \%$ dan suhu pengempaan $200{ }^{\circ} \mathrm{C}$. Bertambahnya intensitas gugus $\mathrm{C}=\mathrm{O}$ seiring dengan penambahan jumlah asam sitrat, seperti yang terlihat pada Gambar 2 , menunjukkan bahwa gugus ester yang terbentuk antara gugus $\mathrm{OH}$ dari bambu dan gugus karboksil dari asam sitrat juga meningkat dan menyebabkan sifat hidrofilik bambu menjadi semakin berkurang (Widyorini et al., 2014, Vukusic et al., 2006).

Gambar 5 dan 6 menunjukkan sifat mekanika papan partikel bambu pada berbagai jumlah asam sitrat (0 - $40 \%$ ) dan suhu pengempaan 200 dan 220 ${ }^{\circ} \mathrm{C}$. Nilai modulus patah dan modulus elastisitas papan partikel bambu memperlihatkan peningkatan dengan bertambahnya jumlah asam sitrat (Gambar 5), tetapi perbedaan suhu tidak menyebabkan pengaruh nyata pada kedua nilai tersebut. Penambahan asam sitrat sebanyak $20 \%$ menghasilkan papan partikel yang memenuhi standar JIS A 5908 tipe 8

Tabel 2. Rekapitulasi hasil analisis

\begin{tabular}{lccc}
\hline \multicolumn{1}{c}{ Parameter } & Jumlah Asam Sitrat & Suhu Kempa & Interaksi \\
\hline Pengembangan tebal & $<0,01 * *$ & $<0,01 * *$ & $<0,01 * *$ \\
Penyerapan air & $<0,01 * *$ & $0,04 *$ & $<0,01 * *$ \\
Modulus patah & $<0,01 * *$ & $0,34 \mathrm{~ns}$ & $0,03 *$ \\
Modulus elastisitas & $<0,01 * *$ & $0,32 \mathrm{~ns}$ & $<0,01 * *$ \\
Kekuatan rekat & $<0,01 * *$ & $<0,01 * *$ & $0,31 \mathrm{~ns}$ \\
internal & & & \\
\hline$* *=$ signifikan taraf uji $0,01 *$ signifikan taraf uji $0,05 \mathrm{~ns}=$ tidak signifikan
\end{tabular}




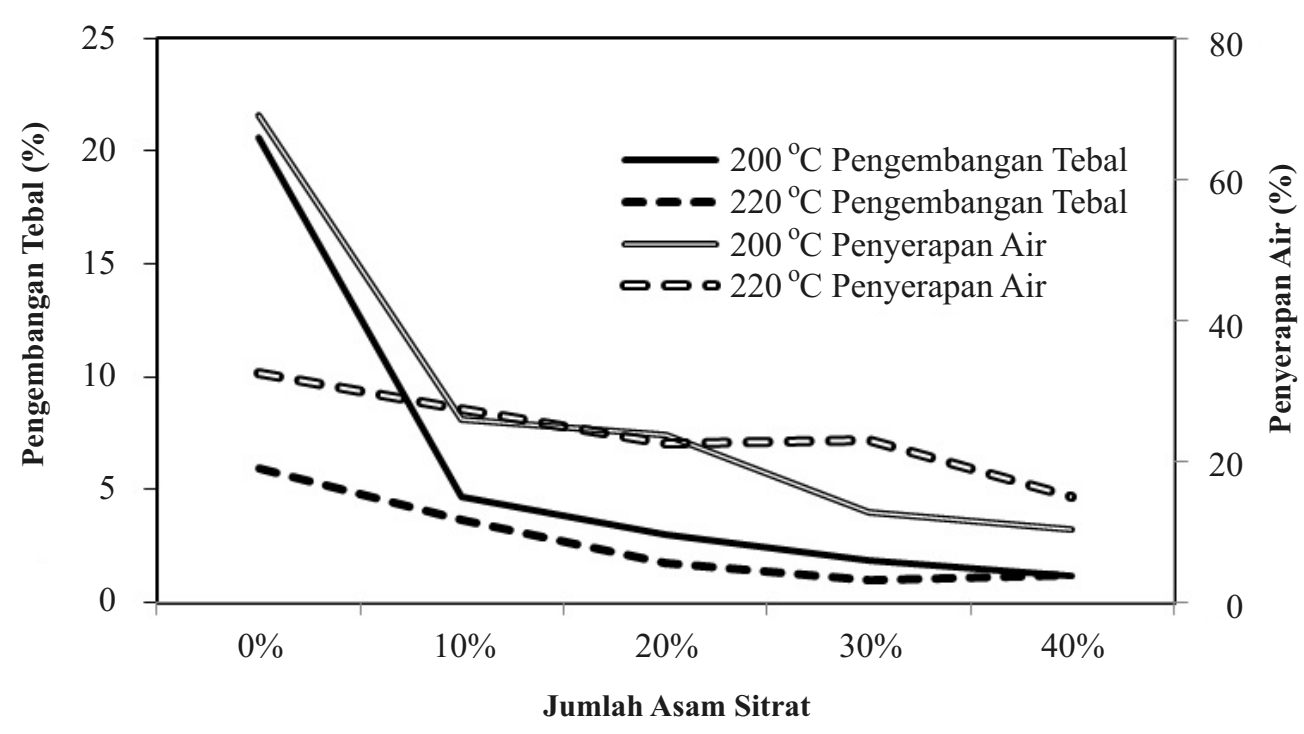

Gambar 4. Nilai pengembangan tebal dan penyerapan air papan partikel bambu pada berbagai jumlah asam sitrat dan suhu pengempaan

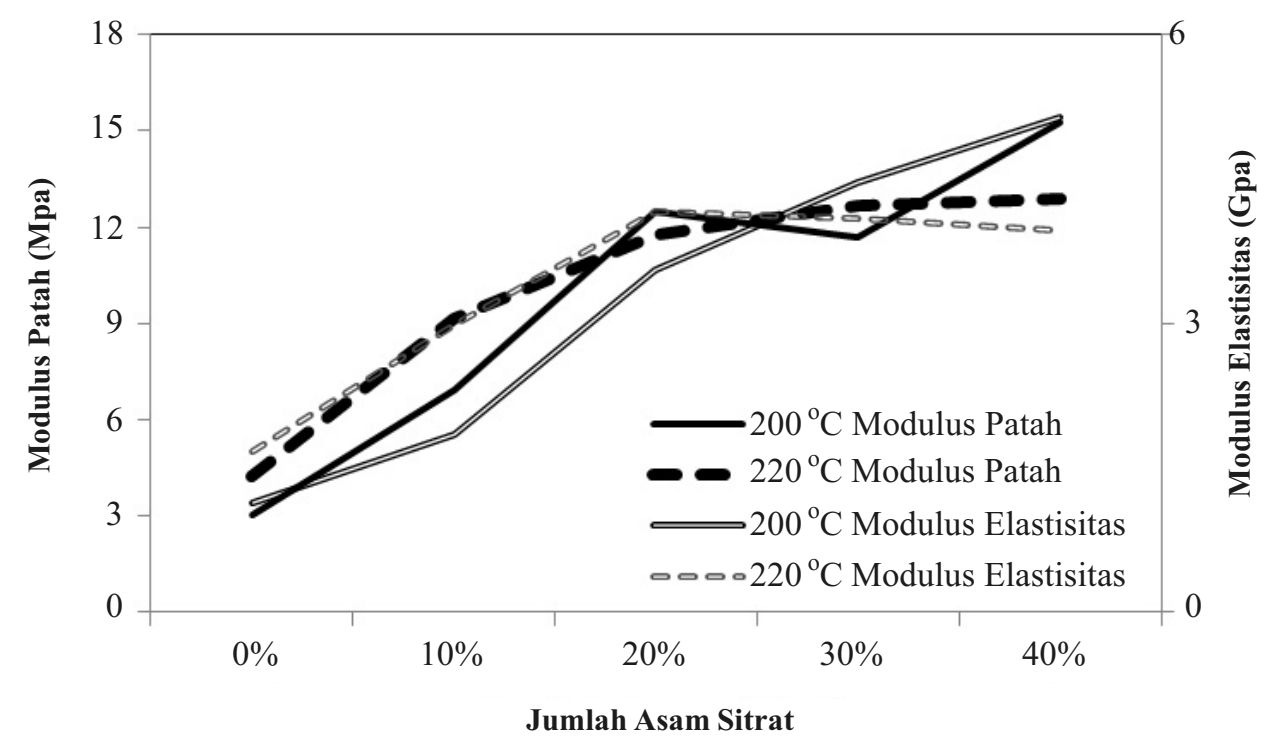

Gambar 5. Nilai modulus patah dan elastisitas papan partikel bambu pada berbagai jumlah asam sitrat dan suhu pengempaan

(modulus patah minimal $8 \mathrm{MPa}$ dan modulus elastisitas minimal $2 \mathrm{GPa}$ ), bahkan nilai modulus elastisitasnya dapat melebihi standar JIS A 5908 tipe 18 (minimal $3 \mathrm{GPa}$ ). Nilai modulus patah dan elastisitas tertinggi diperoleh pada penambahan asam sitrat $40 \%$, dengan nilai modulus patah sebesar 15,28 MPa dan modulus elastisitas 5,14 GPa. Kedua nilai tersebut melebihi standar JIS A 5908 tipe 18.

Penambahan asam sitrat dimaksudkan untuk meningkatkan sifat fisika papan partikel bambu petung, terutama sifat ketahanan terhadap air. Peningkatan stabilitas dimensi terlihat dengan penurunan nilai pengembangan tebal dan penyerapan air seiring dengan penambahan asam sitrat. Penurunan sifat higroskopis ini disebabkan oleh perubahan hemiselulosa bahan baku (Sekino et al., 1999 dalam Widyorini et al., 2005). Di sisi lain, gugus $\mathrm{OH}$ pada bambu berikatan dengan karboksil asam sitrat membentuk ikatan ester (Umemura et al., 2011); McSweeny et al., 2006). Hal tersebut dibuktikan 
dengan keberadaan puncak yang terlihat di sekitar $1720 \mathrm{~cm}^{-1}$ dari pengujian FTIR, seperti sudah diuraikan di atas.

Penambahan asam sitrat menghasilkan papan partikel yang memenuhi standar JIS A 5908, dimana jumlah asam sitrat $40 \%$ dengan suhu pengempaan $200{ }^{\circ} \mathrm{C}$ menghasilkan nilai penyerapan air dan pengembangan tebal papan partikel bambu petung terendah, masing-masing sebesar $12,56 \%$ dan 1,10 $\%$. Peningkatan sifat kestabilan dimensi pada papan partikel bambu petung terjadi seiring meningkatnya penggunaan asam sitrat. Hal ini juga terjadi pada penelitian Umemura et al. (2012), dimana kestabilan dimensi produk molding lebih baik pada penambahan asam sitrat $40 \%$ dibanding $0 \%$.

Sifat mekanika yang diamati pada penelitian ini meliputi keteguhan lengkung statis dan keteguhan rekat internal. Keteguhan lengkung statis diukur melalui pengujian sifat modulus patah dan modulus elastisitas papan partikel bambu petung. Penambahan asam sitrat mempengaruhi nilai modulus patah maupun modulus elastisitas. Nilai modulus patah dan modulus elastisitas papan partikel tanpa penambahan asam sitrat memiliki nilai sebesar 3,04 MPa dan 1,13 GPa pada suhu kempa $200{ }^{\circ} \mathrm{C}$ serta 4,25 MPa dan
1,66 GPa pada suhu kempa $220{ }^{\circ} \mathrm{C}$. Kedua nilai tersebut meningkat seiring dengan peningkatan jumlah asam sitrat. Penambahan $20 \%$ asam sitrat menghasilkan papan partikel yang memenuhi standar JIS A 5908 tipe 8 untuk modulus patah dan tipe 18 untuk modulus elastisitas. Nilai tertinggi modulus patah dan modulus elastisitas pada penelitian ini adalah 15,28 $\mathrm{MPa}$ dan 5,14 GPa. Nilai tersebut diperoleh pada kondisi suhu pengempaan $200{ }^{\circ} \mathrm{C}$ dengan jumlah asam sitrat $40 \%$. Hasil berbeda dihasilkan oleh penelitian Umemura et al. (2012), dimana penggunaan asam sitrat $20 \%$ (setara dengan $25 \%$ per berat kering partikel) pada produk molding menghasilkan sifat mekanika yang optimal. Hal tersebut memperlihatkan bahwa sifat bahan baku turut mempengaruhi keberhasilan ikatan dengan asam sitrat.

Gambar 6 menunjukkan nilai kekuatan rekat internal papan partikel bambu pada berbagai jumlah asam sitrat (0 - $40 \%$ ) dan suhu pengempaan 200 dan $220{ }^{\circ} \mathrm{C}$. Nilai kekuatan rekat internal papan partikel bambu memperlihatkan peningkatan dengan bertambahnya jumlah asam sitrat sampai $20 \%$ kemudian nilainya mengalami penurunan. Perbedaan suhu pengempaan menyebabkan pengaruh nyata

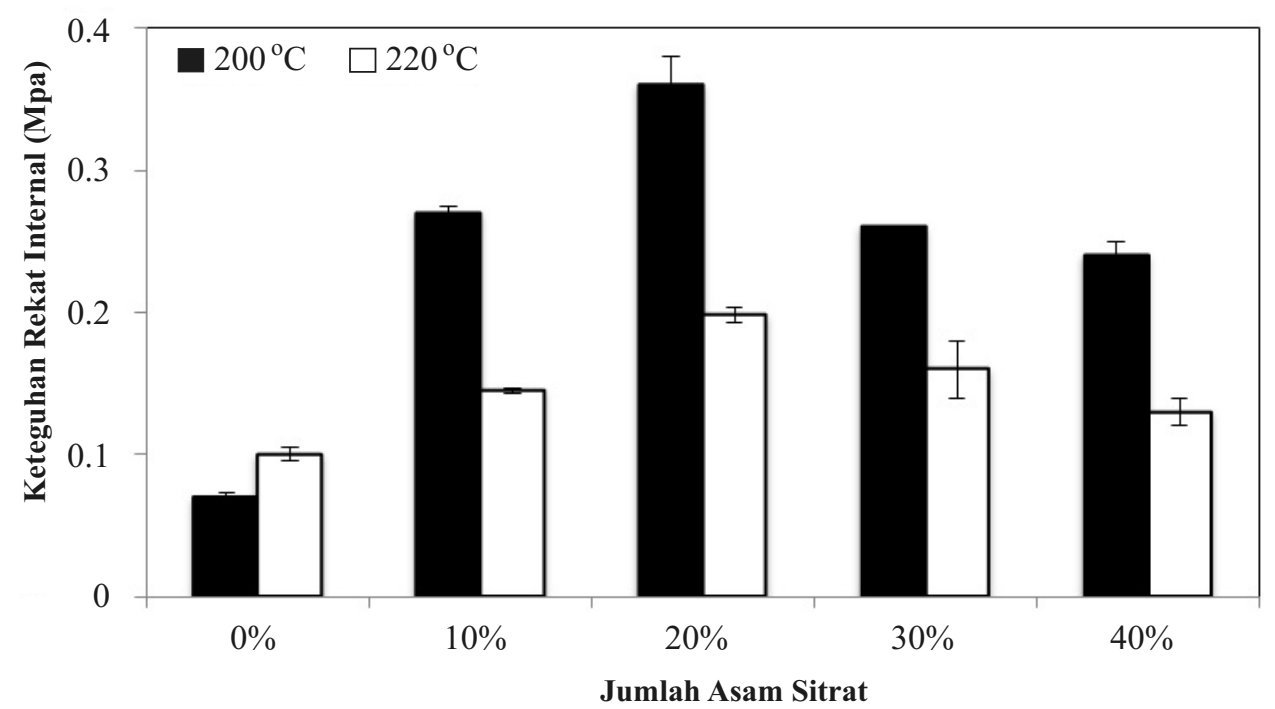

Gambar 6. Nilai kekuatan rekat internal papan partikel bambu pada berbagai jumlah asam sitrat dan suhu pengempaan 
pada nilai kekuatan rekat internal, dimana semakin tinggi suhu menyebabkan penurunan nilai tersebut. Semua papan partikel dengan penambahan asam sitrat dapat memenuhi standar JIS A 5908 tipe 8 (minimal 0,15 $\mathrm{MPa}$ ), bahkan untuk jumlah asam sitrat $20 \%$ dan suhu pengempaan $200{ }^{\circ} \mathrm{C}$, nilai kekuatan rekat internal bisa memenuhi persyaratan tipe 18, yaitu minimal 0,3 MPa.

Nilai keteguhan rekat internal pada penelitian ini berkisar antara 0,07-0,36 MPa. Pembuatan papan partikel tanpa penambahan asam sitrat tidak ada yang memenuhi standar. Dengan penambahan asam sitrat $10 \%$ saja, kekuatan rekat internal papan partikel bambu naik tiga (3) kali pada suhu pengempaan 200 ${ }^{\circ} \mathrm{C}$ dan satu setengah $(1,5)$ kali pada $220{ }^{\circ} \mathrm{C}$. Semua papan partikel dengan penambahan asam sitrat pada suhu pengempaan $200{ }^{\circ} \mathrm{C}$ dapat memenuhi standar JIS A 5908 tipe 13, bahkan untuk penambahan asam sitrat $20 \%$ dapat memenuhi standar JIS A 5908 tipe 18 (lebih dari 0,3 MPa). Menurut Umemura et al. (2012), rata-rata keteguhan rekat internal papan partikel dari softwood yang diberi tambahan asam sitrat hingga $30 \%$ adalah 1,61 MPa (lima kali lebih tinggi dibanding $5 \%$ ).

Suhu kempa yang diberikan selama perlakuan membantu terbentuknya ikatan-ikatan ester antara gugus karboksil dari asam sitrat dengan gugus hidroksil (-OH) dari kayu (McSweeny et al., 2006). Pada penelitian ini, papan partikel yang dikempa pada suhu $200{ }^{\circ} \mathrm{C}$ menghasilkan kualitas papan yang lebih baik dibandingkan papan partikel yang dikempa pada suhu $220{ }^{\circ} \mathrm{C}$ pada waktu pengempaan 10 menit. Hal ini kemungkinan disebabkan oleh suhu pengempaan yang terlalu tinggi sehingga menyebabkan degradasi komponen kimia yang berlebihan dan menyebabkan penurunan kualitas papan (Suzuki et al., 1998).

\section{Mortalitas rayap dan pengurangan berat papan}

Sifat ketahanan rayap yang diamati pada penelitian ini meliputi pengurangan berat papan dan mortalitas rayap. Data hasil penelitian menunjukkan kecenderungan pengurangan berat papan dengan penambahan asam sitrat, seperti terlihat pada Gambar 7. Penambahan asam sitrat $40 \%$ pada suhu $220{ }^{\circ} \mathrm{C}$ menghasilkan pengurangan berat terendah yaitu $0,5 \%$, sedangkan tertinggi sebesar $1,4 \%$ pada suhu yang sama tanpa penambahan asam sitrat (0\%). Penelitian Walther et al. (2007) menunjukkan bahwa pengurangan berat setelah 3 minggu dari kenaf yang diberi perekat fenol formaldehida tanpa impregnasi antara $2 \%$ dan $4 \%$ tergantung pada konsentrasi perekat yang diberikan. Dibandingkan dengan hasil tersebut, papan partikel dengan penambahan asam sitrat pada penelitian ini memperlihatkan ketahanan terhadap serangan rayap kayu kering yang lebih baik.

Mortalitas rayap kayu kering pada papan partikel bambu petung diamati mulai minggu ke-1 hingga minggu ke-6. Pengamatan yang dilakukan pada minggu ke-6 menunjukkan nilai mortalitas rayap berkisar antara 29-78 \%, seperti terlihat pada Gambar 8. Perbedaan suhu pengempaan tidak memberikan pengaruh nyata pada mortalitas rayap, tetapi persentase asam sitrat menyebabkan peningkatan mortalitas rayap, dimana penambahan asam sitrat $10-40 \%$ menyebabkan mortalitas rayap yang tinggi (57-78 \%). Mortalitas rayap kayu kering papan partikel bambu petung dengan penambahan asam sitrat lebih tinggi dibandingkan papan partikel tanpa perekat dari bambu (31\%), bahkan papan komersil (urea formaldehida) sebagai pembanding (38\%), dan tanpa sampel uji (32\%). 


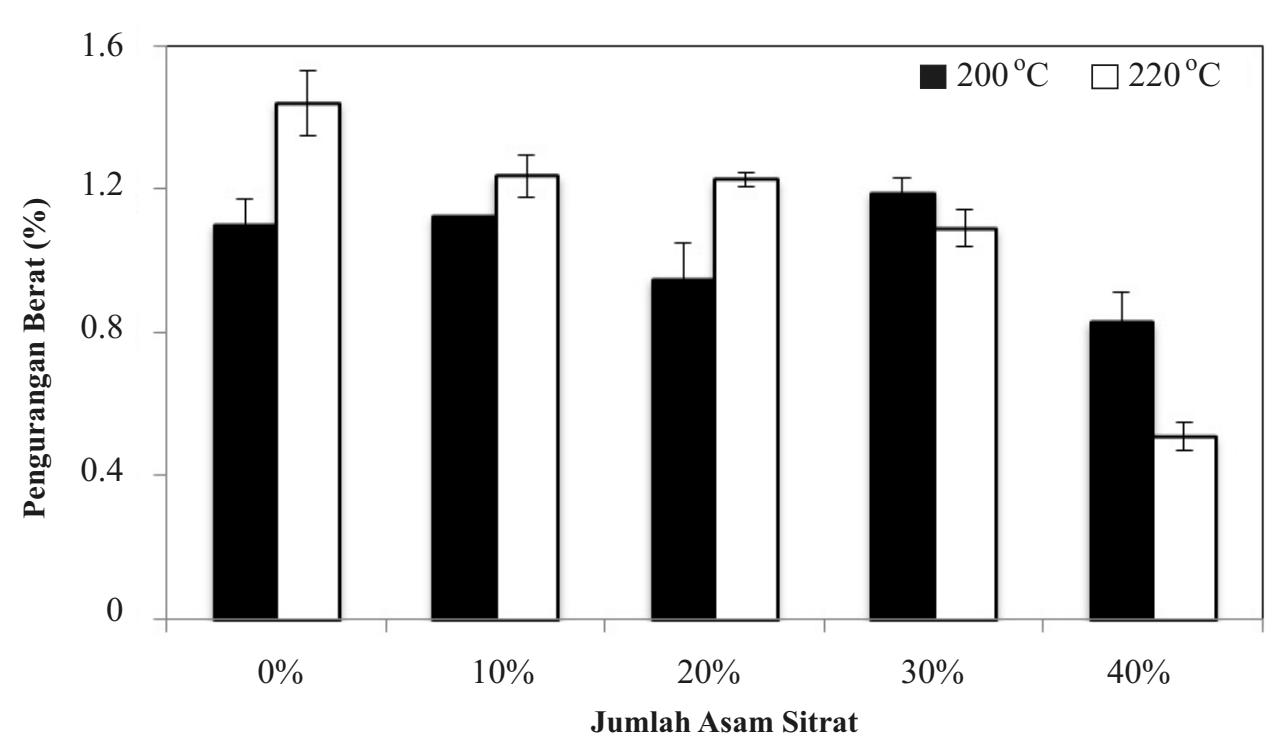

Gambar 7. Nilai pengurangan berat (\%) papan partikel bambu pada berbagai jumlah asam sitrat dan suhu pengempaan

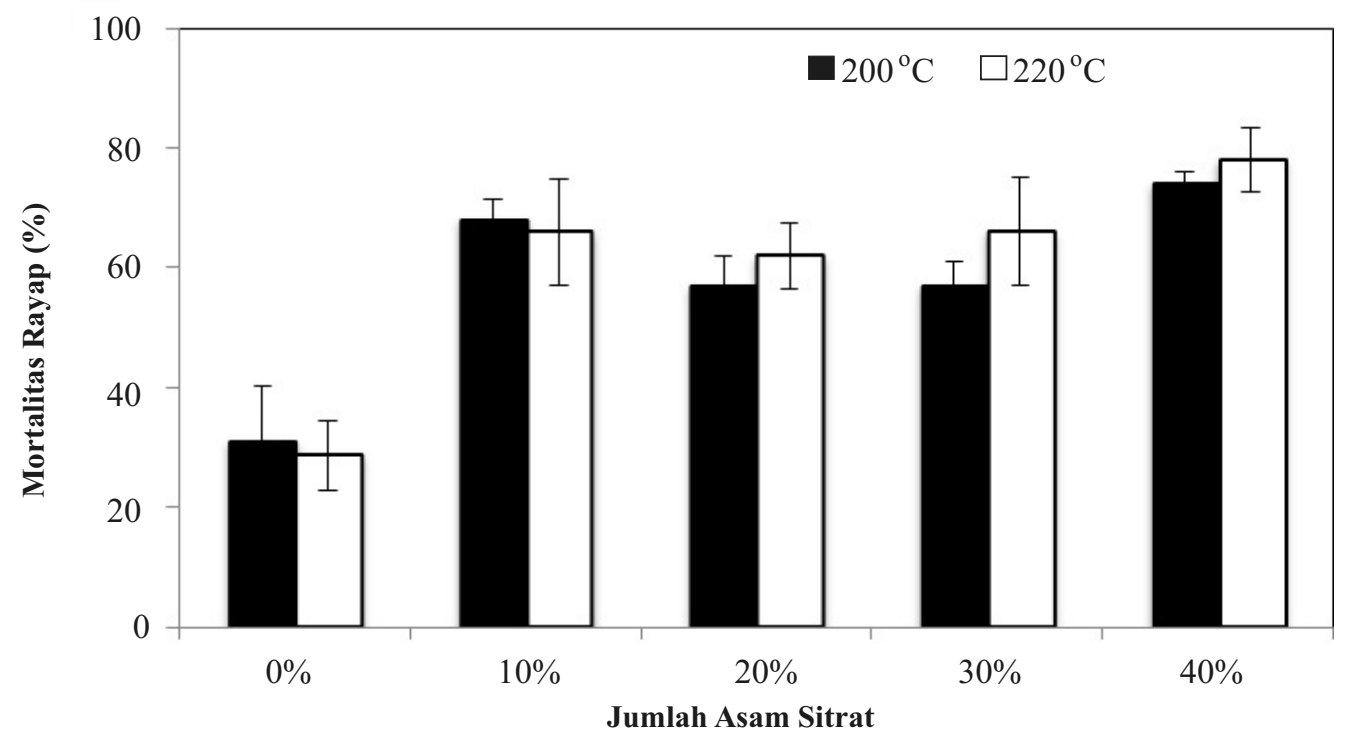

Gambar 8. Nilai mortalitas rayap (\%) papan partikel bambu pada berbagai jumlah asam sitrat dan suhu pengempaan

\section{KESIMPULAN}

Peningkatan sifat fisika dan mekanika papan partikel bambu petung terlihat dengan semakin banyaknya asam sitrat yang ditambahkan. Kondisi optimal pada penelitian ini adalah jumlah asam sitrat $20 \%$ dengan suhu pengempaan papan $200^{\circ} \mathrm{C}$. Pada kondisi tersebut, papan partikel mempunyai nilai pengembangan tebal $3 \%$, penyerapan air $24 \%$, kekuatan rekat internal $0,36 \mathrm{MPa}$, modulus patah 12,5 MPa, dan modulus elastisitas 3,56 GPa. Semua nilai tersebut dapat memenuhi standar JIS A 5908 tipe 8. Hasil penelitian ini menunjukkan bahwa penambahan asam sitrat pada papan partikel dapat menghasilkan papan dengan ketahanan terhadap serangan rayap kayu kering yang baik (57-78 \%). 


\section{UCAPAN TERIMA KASIH}

Penelitian ini merupakan bagian dari Penelitian DPP yang dibiayai oleh Fakultas Kehutanan UGM dengan Surat Perjanjian Pelaksanaan Penelitian Dana DPP Masyarakat nomor 238/KS/2013.

\section{DAFTAR PUSTAKA}

ASTM. 1984. Annual Book of ASTM Standards. American Society for Testing and Materials. Philadelpia.

ASTM . 2002. Annual Book of ASTM Standards. Section Four Construction Volume 04.10 Wood. Baltimore.

Browning BL. 1967. Methods of Wood Chemistry Volume II. Interscience Publisher, John Wiley and Sons, Inc. New York.

Japanese Standard Association. 2003. Japanese Industrial Standard for Particleboard A 5908. Japanese Standard Association. Tokyo.

Japanese Industrial Standard. 2004. JIS K 1571 Test Methods for Determining the Effectiveness of Wood Preservatives and Their Performance Requirements. Japanese Standard Association. Tokyo.

Kamthai S \& Puthson P. 2005. The physical properties, fiber morphology and chemical compositions of sweet bamboo (Dendrocalamus asper Backer). Kasetsart Journal (Natural Science) 39, 581-587.

Laemsak N \& Okuma M. 2000. Development of boards made from oil palm frond II: Properties of binderless boards from steam-exploded fibers of oil palm frond. Journal of Wood Science 46, 322-326.

Liese W. 1985. Bamboos-Biology, Silvics, Properties, Utilization. Deutsche Gesellschaft Fur Technische Zusammenarbeit (GTZ) GmbH. Eschborn. Germany.

McSweeny JD, Rowell RM, \& Min S. 2006. Effect of citric acid modification of aspen wood on sorption of copper ion. Journal of Natural Fibers 3(1), 43-58.

Okuda N \& Sato M. 2006. Water resistance properties of kenaf core binderless boards. Journal of Wood Science 52, 422-428.

Suzuki S, Shintani H, Park SY, Saito K, Laemsak N, Okuma M, \& Iiyama K. 1998. Preparation of binderless boards from steam exploded pulps of oil palm (Elaeis guneensis Jaxq) fronds and structural characteristics of lignin and wall polysaccharides in steam exploded pulps to be discussed for self-bonding. Holzforschung 52, 417-426.

Technical Association for the Pulp and Paper Industries. 1992. Acid-insoluble in wood and pulp. TAPPI Test Method T 222 os-74. TAPPI Press. Atlanta.

Thanh ND \& Nhung HL. 2009. Cellulose modified with citric acid and its absorption of $\mathrm{Pb} 2+$ and $\mathrm{Cd} 2+$ Ions. Proceedings of $13 \mathrm{rd}$ International Electronic Conference on Synthetic Organic Chemistry (ECSOC-13).

Umemura K, Ueda T, Munawar SS, \& Kawai S. 2011. Application of citric acid as natural adhesive for wood. Journal of Applied Polymer Science 123,1991-1996

Umemura K, Ueda T, \& Kawai S. 2012. Characterization of wood-based molding bonded with citric acid. Journal of Wood Science $\mathbf{5 8 , 3 8 - 4 5 . ~}$

Vukusic SB, Katovic D, Schramm C, Trajkovic J, \& Sefc B. 2006. Polycarboxylic acids as non-formaldehyde anti-swelling agents for wood. Holzforschung 60, 439-444.

Walther T, Kartal SN, Hwang WJ, Umemura K, \& Kawai S. 2007. Strength, decay, and termite resistance of oriented kenaf fiberboards. Journal of Wood Science 53, 481-486.

Widyorini R, Higashihara T, Xu J, Watanabe T, \& Kawai S. 2005. Self-bonding characteristics of binderless kenaf core composites. Wood and Science Technology 39, 651-662.

Widyorini R, Yudha AP, Adifandi Y, Umemura K, \& Kawai S. 2013. Characteristics of bamboo particleboard bonded with citric acid. Wood Research Journal 4(1), 31-35.

Widyorini R, Yudha AP, Isnan R, Awaludin A, Prayitno TA, Ngadianto A, \& Umemura K. 2014. Improving the physico-mechanical properties of eco-friendly composite made from bamboo. Advanced Material Research 896, 562-565.

Xu J, Han G, \& Kawai S. 2003. Development of binderless particleboard from kenaf core using steam-injection pressing. Journal of Wood Science 49, 327-332. 